\title{
THE RHODESIAN JOURNAL OF
}

\section{ECONOMICS}

The Quarterly Journal of the Rhodesian Economic Society

Editorial Board:

A. M. Hawkins (Editor), J. A. C. Girdlestone, A. F. Hunt,

D. I. Ramsay and M. L. Rule.

ARTICLES

Page

Energy Planning and Policy

J. H. West

107

Internal Labour Markets in Rhodesia: A Case

Study of Management Responsibility

G. E. Cheater

117

An Evaluation of South Africa's National Physical

Development Plan for Business Decision-Making N. N. Patricios

REVIEW

The City of Salisbury Report on the African Affairs

Section of the Urban Plan

P. Van Hoffen

147

Inflation Accounting $\rightarrow$ A Comment

C. N. Weakley

155

Reply

D. L. Brooking 


\section{ENERGY PLANNING AND POLICY}

BY

J. H. WEST*

\section{World Energy Supply}

World sources of energy are many and varied; they include solar, wind, geothermal, wood, peat, tides, human and animal effort, biological waste and so on. However these are either too small for inclusion in national figures or are too difficult to quantify and therefore, in international statistics, the only sources of energy which are aggregated are coal, oil, natural gas and electricity produced from hydro or nuclear sources. The following table shows how the world supply of energy has increased in the last four decades. Consumption of coal has barely doubled whereas consumption of crude oil has increased more than tenfold and the supply of natural gas has increased twentyfold. Nuclear and hydro electric power have also grown considerably but are still generated from fossil fuels - coal, oil and gas - and about a quarter of the 1972 production shown below was used for this purpose.

\section{TABLE I}

\section{WORLD PRODUCTION OF COMMERCIAL SOURCES OF ENERGY \\ (In Billion Equivalent Tonnes of Coal)}

\begin{tabular}{|c|c|c|c|c|c|}
\hline Year & Coal & Oil & Gas & $\begin{array}{c}\text { Hydro } \\
\text { and } \\
\text { Nuclear } \\
\text { Electricity }\end{array}$ & Total \\
\hline 1929 & 1,41 & 0,28 & 0,08 & 0,01 & 1,78 \\
1937 & 1,40 & 0,38 & 0,10 & 0,02 & 1,90 \\
1950 & 1,61 & 0,70 & 0,26 & 0,04 & 2,61 \\
1960 & 2,20 & 1,40 & 0,62 & 0,09 & 4,31 \\
1970 & 2,40 & 3,00 & 1,43 & 0,16 & 6,99 \\
1972 & 2,43 & 3,34 & 1,62 & 0,18 & 7,57 \\
\hline
\end{tabular}

Source: U.N. Statistical Papers.

\section{A Statistical Snag}

In compiling energy statistics one of the objects is usually to arrive at a figure showing the total national consumption of energy in terms of a common

\footnotetext{
*Energy Resources Adviser to the Rhodesian Prime Minister.
} 
unit which might be kilowatt hours, joules, Btu's or calories. The most easily understood unit is probably equivalent tonnes of coal and this has been used in the table. Conversion factors for turning the other kinds of energy into coal are nearly always based on the calorific content of the particular source. This gives a reasonable picture in the case of oil and gas but many people consider that the results are misleading for hydro and nuclear electricity. In international energy statistics the electricity which is produced from coal is counted as coal whereas the electricity produced from uranium or falling water is counted in terms of the energy in the electricity. Roughly speaking it takes about half a kilogram of coal with an energy content (in Rhodesia) of 15 megajoules to generate one kilowatt hour of electricity with an energy content of 3,6 MJ. Expressed in terms of equivalent tonnes of coal and averaging out the variations between countries in calorific quality of coal, the conversion factor adopted for international use works out at $1 \mathrm{kWh}=0,125 \mathrm{~kg}$ of coal. Adding coal and electricity on this basis can produce some odd results, as the following example will show. The figures are hypothetical but they are of the correct order of magnitude.

Consider the situation in Rhodesia before and after the commissioning of Kariba. Before Kariba 2,0 million tonnes of coal were burned as fuel and 1,5 million tonnes were used to generate 3,0 billion $\mathrm{kWh}$ of electricity. Total energy production was therefore 3,5 million tonnes of coal equivalent.

After Kariba the consumption of coal for fuel was unchanged at 2,0 million tonnes but consumption for the generation of electricity was very low. Let us say that total generation of electricity was 6 billion kilowatt hours per annum, which 0,4 billion was from 0,2 million tonnes of coal and 5,6 billion from water in Lake Kariba. The latter would be converted into coal equivalent on the basis of 0,125 kilograms of coal to one kilowatt hour as explained above and would therefore be valued at 0,7 million tonnes of coal equivalent. Total energy production in Rhodesia would therefore be shown in international statistics as $2,0+0,2+0,7=2,9$ million tonnes of coal equivalent.

In other words total energy production after Kariba was apparently down by $17 \%$ despite the fact that ultimate consumers were using the same amount of coal and twice the amount of electricity.

By comparison we may consider the case of another country with no hydro power but the same total electricity generation as Rhodesia after Kariba. The figures for this hypothetical country would be 2,0 million tonnes of coal used for conversion into electricity. In other words this country would figure in the international energy statistic as consuming 5,0 million tonnes of coal equivalent or nearly twice the figure for Rhodesia. 
It is only in Africa that major sites for the generation of substantial amounts of hydro electric power remain to be developed. The percentage contribution of hydro power to world resources will therefore gradually decline. By contrast the amount of electricity generated from nuclear sources is bound to increase enormously and an absurd situation could be reached in which a country with a very heavy dependence on nuclear power could be recorded as consuming less energy than a country producing only half as much electricity, but doing so from fossil fuels. No doubt before this state of affairs is reached there will have been changes in the method of compiling international energy statistics.

\section{Static Energy Patterns}

Everyone has his own ideas of how energy patterns will change in the future but it is generally accepted that consumption of natural oil and gas cannot continue to increase at the rates recorded in the past few decades. It is true that new sources are being discovered all the time but each one tends to be more expensive than the previous one and therefore the price of oil and gas in relation to other fuels is bound to increase. It is one thing to tap a gusher in Texas but quite another to bring oil ashore from the middle of the North Sea or to squeeze it out of the Athabasca tar sands. Because of this, some people make gloomy prognoses of a declining energy availability per head. However this seems unlikely - unless the industry and ingenuity of mankind is to suffer a decline. Natural oil and gas were virtually unknown fifty years ago and in fifty years time they will probably be exhausted, but mankind will not go short of energy.

By comparison with oil and gas, the reserves of coal are extremely large. Nevertheless most people do not forecast very startling increases in coal production. This is because underground mining is always likely to be a hazardous and unpopular occupation and the potentialities of open cast mining are limited to the realtively small number of fields where the coal is close to the surface. The energy gap is generally expected to be filled mainly by nuclear electricity. Known reserves of uranium may be unable to support a rapidly expanding nuclear power industry for more than a couple of decades but this does not discourage the advocates of nuclear energy. These reserves are based on a very low market price which could be increased substantially without much effect on the cost of electricity. Uranium is not a particularly scarce material; it is believed to constitute about three parts per million of the earth's crust, which places it in about the same category as such metals as tin and lead. The conventional type of nuclear power station is extravagant in its use of fuel but the fast breeder is capable of producing the same amount of energy with only a fiftieth of the amount of fissile material. Three such stations are already in operation, and once the technological problems 
associated with the liquid sodium coolant have been solved there is every likelihood that the fast breeder will become the conventional mode. This may well happen by the turn of the century. After that there is the possibility of using thorium as an alternative to uranium. Thorium exists in prolific quantities and should provide a supply of energy for as long as can be foreseen. Ultimately the fusion process will be perfect, bringing to reality Jules Verne's dream of using water as the ultimate source of energy.

\section{Nuclear Power in Rhodesia}

Although the northern part of Rhodesia is considered a likely prospecting area for uranium it does not seem that any local use of nuclear electricity will be made for many years. One reason is that nuclear power stations cost a great deal more to construct than coal fired power stations. By comparison with coal, uranium fuel is cheap in the highly industrialised countries but this is not the case in Rhodesia. The following table shows that in the United Kingdom, where power station coal costs about $\$ 9$ per tonne, but nuclear fuel costs only $\$ 3$ per equivalent tonne, the operating costs of nuclear stations are in general so low that they more than offset the higher capital costs. The table refers to the hypothetical cost of stations built in 1973. But in practice the Magnox stations built a decade ago are already showing lower costs of generation than fossil fuel fired stations which were built at the same time.

\section{TABLE, II}

COSTS OF NUCLEAR AND COAL FIRED POWER STATIONS (At 1973 Prices in the U.K. Converted to Rhodesian Dollar at $£ 1=\$ 1,3$ )

\begin{tabular}{|c|c|c|c|}
\hline Type & $\begin{array}{l}\text { Cost of } \\
\text { construction, } \\
\text { initial fuel } \\
\text { charge and } \\
\text { interest during } \\
\text { construction }\end{array}$ & $\begin{array}{c}\text { Total operating } \\
\text { costs over } 25 \\
\text { years at } 64 \% \\
\text { load factor and } \\
10 \% \text { discount rate }\end{array}$ & Cost of generation \\
\hline $\begin{array}{l}\text { Nuclear:- } \\
\text { Magnox } \\
\text { Advanced Gas } \\
\text { Cooled } \\
\text { High Temperature } \\
\text { Heavy Water } \\
\text { Pressurised Water } \\
\text { Coal Fired }\end{array}$ & $\begin{array}{c}\text { per kW sent } \\
\text { sut } \\
426 \\
413 \\
313 \\
256 \\
277 \\
242 \\
137\end{array}$ & $\begin{array}{c}\$ \text { per kW sent } \\
\text { out } \\
49 \\
\\
68 \\
82 \\
64 \\
61 \\
257\end{array}$ & 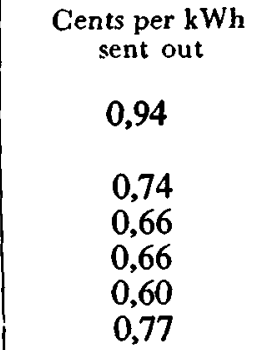 \\
\hline
\end{tabular}

SOURCE: Chairman of the Central Electricity Generating Board and Merz and McLennan. 
Although construction costs in Rhodesia would probably be higher than indicated above, the table gives an idea of how much more expensive it would be to build a nuclear rather than a coal fired station in Rhodesia. And all the extra cost would be in foreign currency. Hydro stations involve even less foreign currency than coal fired stations because they have no steam raising plant and the dam walls are made of local materials. Nuclear fuel would be of wholly foreign content. Another disadvantage of nuclear powered stations sofar as Rhodesia is concerned is that they are most economic when they are large - say over a thousand megawatts, which is more than the total demand for power in Rhodesia today. Moreover most nuclear stations have to be shut down for about a month each year for a partial fuel change. A supply system as small as Rhodesia's would be hard put to accommodate such an arrangement.

\section{Rhodesia's Energy Resources}

For these reasons the main sources of energy in Rhodesia for some considerable time are likely to be the same as at present, namely wood, coal, hydro electricity and imported liquid fuels. Wood has the highest local content and a great deal is still used for domestic purposes in both rural and urban areas. Small amounts are burned as fuel by industries, farms and mines but it must be regarded as a diminishing source. Rhodesia's coal reserves are enormous by comparison with the area which is being commercially mined. Fifteen coal fields are known to exist but estimates of their extractable contents have widely differing degrees of reliability. However it is quite safe to say that Rhodesia has plenty of coal and that a fair proportion is the coking variety which is scarce in the rest of Africa. Coal is sometimes thought of as a wholly local fuel, but in fact it has a small foreign content because it is mined and graded with imported machinery and moved to its destination by railway and road transport which also have an appreciable foreign content. Much the same can be said about electricity. Labour and some other operating costs are local, but the capital costs include major items of foreign equipment such as boilers, turbines, condensers, generators, transformers, and some of the material used in the transmission and distribution systems. Electricity consuming appliances also involve expenditure in foreign currency. Liquid fuels are sometimes thought of as being wholly of foreign origin, but the retail price of 20 cents per litre for petrol includes about 5 cents for customs duty and a further small amount covers payments to the oil companies and transport firms for distribution within Rhodesia. Nevertheless the imported liquid fuels have a much higher foreign content than the other sources of energy and it is government policy, as enunciated in a statement by Senator Wrathall in November 1974, to encourage a switch from imported to local sources. 


\section{Conversion of Static Appliances}

Although the amount of imported fuel used for static purposes in boilers, ovens, furnaces, etc is only a fraction of what is used for mobile purposes in cars, lorries, locomotives and aeroplanes, the efforts to persuade business to convert have obviously been directed at the former, where a degree of success is likely in the short term. A fair number of concerns have already converted their static plant and many more are planning to do so, though the present shortage of foreign exchange means that progress is slower than was originally expected. All conversion plans involve the expenditure of foreign exchange on new equipment and even though this is eventually recouped in the fuel savings, it is nevertheless an initial hurdle. No special incentives are provided to induce firms to convert, because the inducement already exists in the form of the cost differential which is indicated in the following table. To the cost advantages, many firms would add the security of supply factor.

\section{TABLE III}

COMPARATIVE COSTS OF FUELS USED BY INDUSTRIALISTS AS AT JUNE 1975

\begin{tabular}{|l|c|c|c|c|c|}
\hline \multicolumn{1}{|c|}{ Fuel } & Unit & $\begin{array}{c}\text { Cost } \\
\text { in } \\
\text { Cents }\end{array}$ & $\begin{array}{c}\text { Mega- } \\
\text { joules }\end{array}$ & $\begin{array}{c}\text { Cents } \\
\text { Mer } \\
\text { Mega- } \\
\text { joule }\end{array}$ & $\begin{array}{c}\text { Cost } \\
\text { Ratio }\end{array}$ \\
\hline Coal & $\mathbf{k g}$ & 1,1 & 30 & 0,04 & 1 \\
Coke & $\mathbf{k g}$ & 2,6 & 29 & 0,09 & 2 \\
Producer gas & $\mathbf{m}$ & 0,6 & 5 & 0,12 & 3 \\
Coal Tar & $\mathbf{k g}$ & 6,2 & 38 & 0,16 & 4 \\
Electricity & $\mathbf{k W h}$ & 0,6 & 4 & 0,17 & 5 \\
Diesel & litre & 11,3 & 38 & 0,30 & 8 \\
Paraffin & litre & 11,3 & 37 & 0,31 & 8 \\
Petrol (Premium) & litre & 18,9 & 37 & 0,51 & 14 \\
LPG & $\mathbf{k g}$ & 47,0 & 49 & 0,96 & 26 \\
\hline
\end{tabular}

The Colliery company maintains an advisory service for the benefit of firms who wish to consider the various options open to them and there are numerous engineering companies which provide and service the different appliances. The simplest and most popular is the ordinary screw fed coal stoker while for bigger installations there are various sizes of chain grate stokers. For a number of applications where a hot raw gas is required, the pulverised fuel burner is ideal and these are now available in a form in which nearly all the ash is collected before it goes up the chimney.

For large industries and mines, producer gas unit are ideal. Press button starting and electronically controlled fuel supply, water injection and ash 
removal make these appliances clean and convenient. The fact that the gas is of low calorific value is of no significance provided the unit can be placed close to where the heat is required. It is not economic to pipe it any distance. It is possible to obtain a high temperature from producer gas especially when it can be used in a hot raw condition. A cold clean gas can be produced at a slightly higher cost when avoidance of pollution is the critical factor.

Several factories are now using coal tar fuel. This is produced as a byproduct from the coke ovens at Wankic and RISCO. It will not flow at ambient temperature and therefore must be warmed before being burned. Apart from this it is a very suitable substitute for diesel and paraffin because it is a liquid fuel and therefore usually involves less capital expenditure for conversion than do the other methods.

An unusual fuel used with great success in one factory and being considered by others is waste oil. This is simply lubricating oil collected from big users such as garages, but which is not good enough for re-refining. About a third of used oil is in this category because it is contaminated by petrol, diesel, water or dirt. Nevertheless it makes an effective and cheap fuel when used in a locally made burner adapted for this purpose. There are a limited number of cases where electricity can be substituted for imported fuels though as a rule electricity is more suited for lighting and for power than for bulk heating. Nevertheless when very high temperatures are needed, as is frequently the case in the ore refining industry, the arc furnace is the normal method.

Solar energy is beginning to make a niche for itself in the industrial and agricultural fields. It is a very suitable means for providing hot water in wash rooms in factories and public institutions where the demand is at the middle of the day and the late afternoon. Solar heating is most economic when it is installed during construction rather than added on afterwards. There are interesting possibilities of using the roof of a building as the heat transfer medium and so reducing the cost of the collector. In agriculture, solar heating is an excellent method of crop drying. It involves little more than putting an extra skin on the roof of a building which is properly orientated towards the sun, and sucking air between the two skins into a bin containing the crop. The gentle heat which is provided is particularly suitable for the purpose. Solar energy can be used to produce high temperatures, but only by the use of mirrors which involve elaborate and expensive apparatus to track the sun. For this reason solar heating has not been used for curing tobacco though it is being used in a few places, on the roof collection principle, as a method of preheating air before it goes into the furnace, thus saving some of the fuel which would otherwise be used. Nearly all the materials which go into the manufacture of solar heaters are imported and it is government policy to encourage the use of local materials such as cement and wood. 
Windmills are sometimes used to pump water on farms, and if the site is correctly chosen they are cheaper than diesel pumps. Attempts have been made in many countries to utilize wind power for the generation of electricity but there are very few places in Rhodesia where the wind is strong enough or consistent enough to make this feasible. There is however a wind generator on an island in Lake Kariba which powers a radio transmitter for sending meteorological information to Kariba town. There may be a few localities, a long way from the E.S.C. supply area, where the wind could be used to generate enough power for a small lighting set, but Rhodesian winds are much too unreliable for industrial use.

The manufacture of town gas from coal is being investigated by the Bulawayo Municipality. Bulawayo is much closer to Wankie than Salisbury and therefore coal is cheaper. Moreover the industries it is hoped to supply are more concentrated than in Salisbury and therefore the cost of pipelines would be relatively low.

Several municipal sewage farms produce bio-gas as a by-product of the anaerobic fermentation of domestic wastes. About two thirds of it is methane, which is the main constituent of natural gas and has a high calorific value. The other third consists of inert gases and impurities. Some of this gas is sold for industrial purposes in Salisbury but with one exception the sites are too far from the industrial areas to make piping it an economic proposition. There is however scope for the production of methane on farms and the government is co-operating with a Norton farmer in the construction of an experimental digester. The bio-gas which it will produce will power a stationary engine and will also be used to heat air for curing tobacco.

\section{Conversion of Vehicles}

The conversion of motor vehicles to the use of local fuel is a much more difficult and long term problem than the conversion of static appliances. Several people in Rhodesia have made producer gas units and used them to drive vehicles in lieu of petrol. A producer gas generator is a small furnace in which a carboniferous fuel, usually charcoal, is burned with a limited supply of air in order to produce the maximum of carbon monoxide. Producer gas generates only about half as much power as petrol and small units demand a fair amount of attention. Nevertheless they are effective, particularly for vehicles which travel a long distance without many starts or stops and which do not require to travel at a high speed. If the gas is not properly cleaned however it will reduce engine life appreciably.

In his opening address to Parliament in July 1975 the President said "It is well known that Rhodesia has large deposits of coal which could be readily exploited. Considerable experimentation has been proceeding with a view 
to the production in Rhodesia, of liquid fuels from coal. This work will be continued and it is hoped, in due course, to reduce Rhodesia's dependence on imported fuels." Apart from the work which is being carried out for the government, a mining company has announced that it is also making investigations into the possibility of producing oil from coal. Coal is not the only possible source of alternative fuels; farm products such as maize, molasses and potatoes were used on a large scale during World War II for this purposes. There are several countries where molasses are still so used. The economics of manufacturing these substitutes in Rhodesia are under careful study at the present time.

Electric vehicles are another promising avenue of exploration. Where traffic is sufficiently dense electric traction on the railways is more economic than diesel. The difficulty is that it is not possible to electrify on a piece meal basis; it is necessary to deal with a whole section of the route and to acquire a stud of electric locomotives before the conversion can be made. At least one section of the Rhodesia Railways network would be well worth electrifying but the large amount of capital expenditure which this would involve is a major hurdle.

A mode of passenger transport which is becoming popular overseas is the tram-train. This is a light electric railway with overhead conductors and capable of moving large numbers of people at relatively low cost. It is very much cheaper than a main line electric system. The Minister of Local Government and Housing said in September, 1974, that such a railway might be suitable for transportation between Salisbury and the new town proposed for Seki.

Battery powered vehicles offer interesting posibilities. This is because a wide range of electric motors is already made in Rhodesia, whereas the manufacture of internal combustion engines has been regarded as too difficult. Batteries are also made in Rhodesia and even if the conventional type of lead acid battery is eventually superseded by more advanced types with improved power to weight ratios, it is highly likely that they will be capable of being made or largely made in this country. It is this sort of consideration which lay behind the announcement by the Minister of Commerce and Industry in July 1974 that sympathetic consideration would be given to requests for foreign currency for research and development in this field. Even with the existing batteries there are numerous applications for which the lighter types of battery vehicle are ideal. These include movement of personnel and goods within buildings or between buildings in a factory or other limited area. They are particularly adapted for use in hospitals, airports and railway stations. They are suited to roles in which there is a lot of stop-start operation, such 
as messenger services, delivering milk and chemist's sundries, attending parking meters or carrying golfers. The Dairy Marketing Board recently started operating pedestrian controlled trolleys in Salisbury.

Battery powdered passenger cars designed as commuter vehicles are on sale in several countries. Such vehicles typically have a range of $70 \mathrm{~km}$ and a top speed of $70 \mathrm{~km}$ per hour, so they are not competitive with petrol cars in terms of performance. Even so there are places where their pollution free characteristics make them attractive. If as seems likely, the price of imported fuel continues to rise relative to electricity, and there is a substantial improvement in the performance of batteries, then there is a bright future for the battery car. In a couple of decades the manufacture of these vehicles as well as the lighter types which already have an acknowledged role, may be one of Rhodesia's largest industries.

\section{Coordination.}

Government's efforts to promote research and development in all these fields and to keep in contact with similar efforts in other countries are coordinated through the Cabinet Committee on Energy Resources which was set up by the Prime Minister in December, 1973. 


\section{(c) (1) (9)}

This work is licensed under a

Creative Commons

Attribution - NonCommercial - NoDerivs 3.0 License.

To view a copy of the license please see:

http://creativecommons.ora/licenses/bv-nc-nd/3.0/ 